\title{
Meslek Yüksekokulunda Eğitim Gören Birinci Sınıf Öğrencilerinin, Sağlık Çalışanlarına Bulaşan Enfeksiyon Hastalıkları Konusundaki ve Kendi Bağışıklıkları Hakkındaki Bilgi ve Farkındalık Düzeyleri
}

\author{
The Level of Knowledge and Awareness Levels of 1. st Year Students Studying, \\ in Vocational School About Infectious Diseases Transmitting to Health Workers \\ and Their Own Immune Status
}

\author{
Ergin Sarar ${ }^{1}$, Figen Kadakal ${ }^{1}$, Özgür Çelik ${ }^{1}$, Sema Saraç², Barış Yılmaz ${ }^{1}$ \\ ${ }^{1}$ Avrupa Meslek Yüksekokulu, İstanbul, Türkiye \\ ${ }^{2}$ Sağhlk Bilimleri Üniversitesi Süreyyapaşa Göğüs Hastalıkları ve Göğüs Cerrahisi Eğitim ve Araştırma Hastanesi
}

Yazışma Adresi / Correspondence:

Figen Kadakal

Avrupa Meslek Yüksekokulu, İstanbul, Türkiye

T: +90532727 7077 E-mail: : figenkadakal @yahoo.com

Geliș Tarihi / Received : 16.12.2019 Kabul Tarihi / Accepted : 03.01.2020

Orcid :

Figen Kadakal https://orcid.org/0000-0003-0762-5671

Ergin Sarar https://orcid.org/0000-0002-4695-661x

Özgür Çelik https://orcid.org/0000-0002-5660-2831

Sema Saraç https://orcid.org/0000-0002-1629-7035

Barış Yılmaz https://orcid.org/0000-0001-9827-0620

(Sakarya Tip Dergisi / Sakarya Med J 2020, 10(1):1-10 ) DOI: 10.31832/smj.659533

Öz

Amaç Enfeksiyon hastalıkları; sağlık işkolunda çalışanların mesleki riskleri arasında çok önemli bir rol oynar. Bu çalışmada, bir meslek yüksekokulundaki sağlık programlarında eğitim gören, birinci sınıf öğrencilerinde, sağlık çalışanlarına bulaşan enfeksiyon hastalıkları konusundaki bilgi ve farkındalık düzeyleri ile kendi bağıșıklık durumları hakkındaki bilgi düzeylerinin araştırılması amaçlanmıștır.

Gereç ve Araștırma, bir meslek yüksekokulunda bulunan sağlık alanındaki programlarda eğitim gören öğrencilerin, bulașıcı hastalıklar konusundaki bilgilerini belirlemek amacıyla, Yöntemler kesitsel, tanımlayıcı olarak planlanmıștır. Araștırmanın evreni, çalıșmanın yapıldığı tarihlerde meslek yüksekokulunda eğitim almakta olan 1. Sınıf öğrencilerinden ( $\mathrm{n}=192)$ (\%55.20’si kadın, \%44.80’i erkek) olușturulmuștur. Veriler, frekans, yüzdelik dağılımlar, tanımlayıcı istatistiksel metodlar ve Ki-kare testi kullanılarak analiz edilmiştir

Bulgular Öğrencilerin, daha önce bulaşııı hastalık geçirip geçirmedikleri sorusuna (\%13) oranında "evet", (\%21.40) oranında "hayır” ve (\%65.60) oranında ise "bilmiyorum” yanıtını verdikleri belirlenmiștir. Öğrencilerin (\%27.60)'ının ise hangi bulașıcı hastalıkları geçirdiklerini bilmedikleri saptanmıștır

Öğrencilerin "Hepatit A așısı olup olmadıkları" ile ilgili soruya verdikleri yanıtlar incelendiğinde (\%32.30)'unun "evet", (\%44.30)'unun "hayır", (\%23.40)'ının ise "bilmiyorum” yanıtını verdikleri görülmektedir. Aynı soru Hepatit B için sorulduğunda, (\%39.60) “evet”, (\%36.50) "hayır”, (\%24) ise ”bilmiyorum” yanıtı belirlenmiștir.

Sonuç Bu çalıșmanın sonucunda, meslek yüksekokulu birinci sınıfta okuyan öğrencilerin, sağlık çalışanlarına bulaşan enfeksiyon kontrolü konusundaki bilgi ve farkındalık düzeylerinin ve kendi bağışılık durumları hakkındaki bilgilerinin çok yeterli olmadığı belirlenmiştir.

Anahtar Enfeksiyon; Meslek Yüksekokulu;Sağlık çalışanları; Bulaşııı hastalık

Kelimeler

Abstract

Objective Infections diseases play a very important role in the occupational risks of workers in the health sector. In this study, it was aimed to investigate the knowledge and awareness levels of infectious diseases transmitted to health workers and their own immune status among the first year students who were educated in health programs in a vocational school.

Materials The research was planned as a cross-sectional identifier to determine the knowledge of infectious diseases of the students who are in vocational school and who are trained in health programs. and Methods The universe of the study was formed from the first year students ( $n=192)(55.20 \%$ female and $44.80 \%$ male) who were studying at the vocational school at the time of the study. The data was analyzed using frequency, percentile distributions, descriptive statistical methods, and Chi-square test.

Results the students had been asked whether they had infectious disease before and (13\%) answered "yes", (21.40\%) answered "no" and (65.60\%) answered that they did not know. In addition, $(27.60 \%)$ of the students who answered "yes" did not know what infectious diseases they had. The students had been asked whether they had vaccination for Hepatitis A before the responses were, (32.30\%) "yes", (44.30\%) "no", and (23.40\%) mentioned they did not know. When the same question was asked for Hepatitis B, the answer was (39.60\%) "yes", (36.50\%) "no", and (24\%) ( no) knowledge about it.

Conclusion As a result of this study, it was determined that the level of knowledge and awareness about infection control transmitted to health workers by the students studying in the first grade of vocational school and their knowledge about their own immune status were found as insufficient

Keywords Infection; Vocational School; Health workers; Infectious disease 


\section{Giriş}

Dünya Sağlık Örgütü’ne göre sağlık çalışanı, "toplumun sağlığını iyileştirme, koruma ve geliştirme işiyle uğraşan tüm insanlar" olarak tanımlanmıştır. ${ }^{1}$ Sağlık çalışanlarının sağlığını etkileyen tehlike ve riskler literatürde; kimyasal, fiziksel, biyolojik, ergonomik ve psikososyal olarak gruplandırılmıştır. Sağlık çalışanlarının, çalışma koşulları sebebiyle risk altında kaldıkları en önemli etkenlerden biri de biyolojik olanlardır. Biyolojik ajanlar, birçok enfeksiyon hastalığının sebebi olarak gösterilmektedir. ${ }^{2,3}$ Amerika Birleşik Devletlerinde yayımlanan 1983 tarihli raporda, sağlık çalışanlarının diğer çalışanlara göre enfeksiyon hastalıklarına 10 kat daha fazla yakalandıkları bildirilmiştir. ${ }^{4}$ Sağlık işkolunda görev yapanların bu enfeksiyonların özelliklerini, bulaşma yollarını, bu enfeksiyonlardan korunma yollarını, kendi bağışıklık durumlarını bilmeleri ve bu yöntemleri doğru uygulamaları, onların hastalanmalarını önleyen en etkin yoldur. Sağlık alanında eğitim gören öğrencilerin de bu enfeksiyonları, kendi bağışıklık durumlarını ve korunma yöntemlerini yeterince bilmeleri ve mesleklerine başlamadan önce bu konudaki farkındalıklarının artması, sağlık işkolunda çalışmaya başladıklarında, enfeksiyon hastalıklarından korunmalarını sağlayacaktır. Bu durum sağlık çalışanının sağlığı ile beraber toplumun sağlı̆̆ı açısından da koruyucu olacaktır.

Çalışmamızda, meslek yüksekokulunda sağlık programlarının birinci sınıflarında eğitim gören öğrencilerin bu konudaki bilgileri, kendi bağışıklık durumu hakkındaki bilgileri ve farkındalık düzeylerinin değerlendirilmesi amaçlanmıştır. Elde edilecek sonuçlar, sağlık alanında çalışmaya başlamadan önce, öğrencilerin bu konu hakkındaki eğitiminde yol gösterici olacaktır.

\section{Gereç ve Yöntemler}

Araştırma, meslek yüksekokulunda bulunan, sağlık alanındaki programlarda eğitim gören öğrencilerin bulaşıcı hastalıklar ve kendi bağışıklıkları konusundaki bilgilerini belirlemek amacıyla, kesitsel tanımlayıcı olarak planlanmıştır. Araştırmanın evreni, çalışmanın yapıldığı tarih- lerde (Nisan 2019-Haziran 2019) meslek yüksekokulunda eğitim almakta olan 1. Sınıf öğrencilerinden $(n=192)$ (\%55.20’si kadın, \%44.80’i erkek) oluşturulmuştur. Veri toplama aracı olarak literatür doğrultusunda araştırmac1lar tarafından hazırlanan ve çoktan seçmeli olan toplam 26 sorudan oluşan değerlendirme formu kullanılmıştır. Değerlendirme formunda, 7 adet demografik verileri içeren soru, 5 adet yakın çevre bilgisini içeren soru, 14 adet hastalıklarla ilgili (5 adet bilgi düzeyini ölçen) soru mevcuttur. Veriler sınıf ortamında, öncelikle öğrencilere araştırmanın amacı hakkında bilgi verildikten sonra, çalışmaya katılmayı kabul eden öğrencilere değerlendirme formu uygulanarak toplanmıştır. Bu çalışma, gerekli yasal ve etik izinler (25.07.2019 tarih 116.2017.099 sayıl1) sonrasinda yapılmıştır. Veriler, tanımlayıcı istatistiksel metodlar ve ki-kare testi kullanılarak analiz edilmiştir.

\section{Bulgular}

Katılımcıların yaş değişkenine göre dağılımları incelendiğinde en fazla yaş dağılımının “20-21” yaş arasında olduğu saptanmıştır. (\%38.50) Cinsiyet değişkenine göre incelendiğinde kadın sayısının erkek sayısından fazla olduğu belirlenmiştir. (\%55.20)

Katılımcıların eğitim durumu değişkenine göre dağ1lımları incelendiğinde, \%28.60’ının sağlık meslek lisesi, \%71.40’ının ise diğer liselerden mezun oldukları görülmektedir (Tablo 1).

Katılımcıların çalışma durumlarına göre dağılımları incelendiğinde \%77.60’ının (n=149) çalışmadığ \%22.40'ının ( $\mathrm{n}=43)$ ise çeşitli işlerde çalıştıkları görülmektedir.

Katılımcıların okumakta oldukları programa göre dağ1lımları incelendiğinde en fazla (\%23.40) oranıyla fizyoterapi, daha sonra (\%21.90) oranıyla tıbbi laboratuvar teknikleri programlarında okumakta oldukları görülmektedir (Tablo 2). 
Sakarya Tip Dergisi 2020;10(1):1-10

SARAR ve Ark., Meslek Yüksekokulunda Eğitim Gören Öğrencilerin Bulaşııı Enfeksiyonlar Hakkındaki Bilgi ve Farkındalık Düzeyleri

Tablo1. Demografik Veriler; öğrencilerin "yaş, cinsiyet ve eğitim durumuna" göre dağılım oranları

\begin{tabular}{|l|c|c|}
\hline Yaş & Frekans $\mathbf{( N )}$ & Yüzde (\%) \\
\hline 18 den küçük & 9 & 4.70 \\
\hline $18-19$ & 53 & 27.60 \\
\hline $20-21$ & 74 & 38.50 \\
\hline 21 üzeri & 56 & 29.20 \\
\hline Toplam & 192 & 100.00 \\
\hline Cinsiyet & Frekans (N) & Yüzde (\%) \\
\hline Kadın & 106 & 55.20 \\
\hline Erkek & 86 & 44.80 \\
\hline Toplam & 192 & 100.00 \\
\hline Ĕgitim Durumu & Frekans (N) & Yüzde (\%) \\
\hline Sağlık Meslek Lisesi & 55 & 28.60 \\
\hline Diğer Liseler & 137 & 71.40 \\
\hline Toplam & 192 & 100.00 \\
\hline
\end{tabular}

\section{Tablo 2. Öğrencilerin okulda katıldıkları programlara göre} dağılım oranları

\begin{tabular}{|l|c|c|}
\hline Okudukları program & Frekans (N) & Yüzde (\%) \\
\hline Tibbi Görüntüleme Teknikleri & 24 & 12.50 \\
\hline Tibbi Dokümantasyon ve Sekreterlik & 17 & 8.90 \\
\hline İlk ve Acil yardım & 24 & 12.50 \\
\hline Fizyoterapi & 45 & 23.40 \\
\hline Ağız ve Diş Sağlığ1 & 25 & 13.00 \\
\hline Çocuk Gelişimi & 11 & 5.70 \\
\hline Odyometri & 4 & 2.10 \\
\hline Tibbi Laboratuvar Teknikleri & 42 & 21.90 \\
\hline Toplam & 192 & 100.00 \\
\hline
\end{tabular}

Yaşama șekli ve yakın çevre bilgilerine bakıldığında öğrencilerin yaşadıkları çevre ile ilgili olarak \%12'sinin $(\mathrm{n}=23)$ evde tek başına, \%10.90'ının ( $\mathrm{n}=21)$ evde arkadaşlarıyla, \%63.50'sinin ( $\mathrm{n}=122)$ evde ailesiyle, \%13.50'sinin ( $\mathrm{n}=26)$ yurtta kaldığı görülmektedir.

Öğrencilerin anne eğitim durumuna göre dağılımları incelendiğinde, \%56.80'inin ilkokul ve altı, baba eğitim durumuna göre dağılımları incelendiğinde, \%54.20’sinin ortaokul ve üzeri düzeyinde eğitime sahip oldukları görülmektedir (Tablo 3), (Tablo4).
Tablo 3. Öğrencilerin, anne eğitim durumuna göre dağılım oranları

\begin{tabular}{|l|c|c|}
\hline Anne eğitim durumu & Frekans (N) & Yüzde (\%) \\
\hline İlkokul ve altı & 109 & 56.80 \\
\hline Ortaokul ve üzeri & 83 & 43.20 \\
\hline Toplam & 192 & 100.00 \\
\hline
\end{tabular}

Tablo 4. Öğrencilerin, baba eğitimi durumuna göre dağılım oranları

\begin{tabular}{|l|c|c|}
\hline Baba eğitimi durumu & Frekans $\mathbf{( N )}$ & Yüzde (\%) \\
\hline İlkokul ve altı & 88 & 45.80 \\
\hline Ortaokul ve üzeri & 104 & 54.20 \\
\hline Toplam & 192 & 100.00 \\
\hline
\end{tabular}

Öğrencilerin anne mesleğine göre dağılımları incelendiğinde, \%19.80'inin ( $\mathrm{n}=38)$ çalışan, \%80.20'sinin $(\mathrm{n}=154)$ ise ev hanımı oldukları görülmektedir.

Öğrencilerin baba mesleğine göre dağılımları incelendiğinde, \%33.30'unun ( $n=64)$ iş̧i, \%1.60'inın ( $n=3)$ çiftçi, \%18.20'sinin ( $\mathrm{n}=35)$ memur, \%22.90'ının $(\mathrm{n}=44)$ esnaf, \%24'ünün $(\mathrm{n}=46)$ ise diğer mesleklere sahip oldukları görülmektedir.

Hastalık durumuyla ilgili sorularda, daha önce herhangi bir bulaşıcı hastalık geçirip geçirmedikleriyle ilgili soruda, öğrencilerin \%65.60’ının ( $\mathrm{n}=126)$ (bilmiyorum) yanıtını verdikleri görülmektedir (Tablo5).

\begin{tabular}{|l|c|c|}
\hline $\begin{array}{l}\text { Tablo 5. Öğrencilerin “bulaşıcı hastalık geçirdiniz mi?” sorusu- } \\
\text { na göre verdikleri yanıtların oranı }\end{array}$ \\
\hline Bulaşıcı hastalık geçirdiniz mi? & Frekans (N) & Yüzde (\%) \\
\hline Evet & 25 & 13.00 \\
\hline Hayır & 41 & 21.40 \\
\hline Bilmiyorum & 126 & 65.60 \\
\hline Toplam & 192 & 100.00 \\
\hline
\end{tabular}

Öğrencilerin, daha önce hangi bulaşıcı hastalıkları geçirdikleri ile ilgili olan soruya, \%19.80'inin (n=38) kızamık, \%35.40’ının ( $\mathrm{n}=68$ ) suçiçeği, \%6.30'unun ( $\mathrm{n}=12$ ) kızamıkçık yanıtını verdikleri görülmektedir. Buna karşılık öğrencilerin \%27.60'ının $(\mathrm{n}=53)$ ise hangi bulaşıcı hastalıkları 
geçirdiklerini bilmedikleri belirlenmiştir.

Öğrencilerin, bulaşıcı hastalıklardan hangilerine karşı aşıları olduğuna ilişkin olan soruya verdikleri yanttlar incelendiğinde, \%50'sinin ( $\mathrm{n}=96)$ hangi hastalıklara karşı aşıları olduğunu bilmediği saptanmıştır. En fazla yanıtın kızamık ve tetanoz aşısı olduğu belirlenmiştir (Tablo 6).

\begin{tabular}{|c|c|c|}
\hline \multicolumn{3}{|c|}{$\begin{array}{l}\text { Tablo 6. Öğrencilerin “hangi aşıları yaptırdınız?” sorusuna } \\
\text { göre verdikleri yanıtların oranı }\end{array}$} \\
\hline $\begin{array}{l}\text { Öğrencilerin hangi aşıları } \\
\text { yaptırdınız? }\end{array}$ & Frekans $(\mathrm{N})$ & Yüzde (\%) \\
\hline Kızamık & 20 & 10.40 \\
\hline Kızamıkçık & 2 & 1.0 \\
\hline Kabakulak & 2 & 1.0 \\
\hline Tetanoz & 38 & 19.80 \\
\hline Suçiçeği & 6 & 3.10 \\
\hline Çocuk felci & 3 & 1.60 \\
\hline Grip & 9 & 4.70 \\
\hline Bilmiyorum & 96 & 50.0 \\
\hline Kızamık, Kabakulak & 1 & 0.50 \\
\hline Kizamık, Tetanoz & 1 & 0.50 \\
\hline Kızamık, Suçiçeği & 1 & 0.50 \\
\hline Kizamık, Grip & 1 & 0.50 \\
\hline Kızamıkçık, Tetanoz & 1 & 0.50 \\
\hline Tetanoz, Suçiçeği & 1 & 0.50 \\
\hline Suçiçeği, Çocuk felci & 1 & 0.50 \\
\hline Kızamık, Kabakulak, Tetanoz & 1 & 0.50 \\
\hline Kızamık, Tetanoz, Suçiçeği & 6 & 3.10 \\
\hline Kızamık, Suçiçeği, Grip & 1 & 0.50 \\
\hline Kabakulak, Suçiçeği, Grip & 1 & 0.50 \\
\hline Toplam & 192 & 100.00 \\
\hline
\end{tabular}

Öğrencilerin Hepatit A aşıları olup olmadıkları ile ilgili soruya verdikleri yanıtlar incelendiğinde \%23.40’ının ( $n=45)$ "bilmiyorum" yanıtını verdikleri görülmektedir. Hepatit B aşıları olup olmadıkları ile ilgili soruya verdikleri yanıtlar incelendiğinde \%24'ünün ( $\mathrm{n}=46)$ "bilmiyorum" yanıtını verdikleri görülmektedir (Tablo 7).

Öğrencilerin, (Hepatit B taşıyıcılı̆̆g ile ilgili kan testi yaptırdınız mı?) sorusuna \%32.80'inin ( $\mathrm{n}=46$ ) “evet”, \%67.20'si- $\operatorname{nin}(\mathrm{n}=129)$ ise "hayır" yanıtını verdikleri görülmektedir. Öğrencilerin Hepatit B taşıyıcısı olup olmadıklarına ilişkin yantları incelendiğinde ise \%2.10'unun ( $\mathrm{n}=4)$ "evet", $\% 63.50$ 'sinin $(\mathrm{n}=122)$ "hayır" ve \%34.40' $1 \mathrm{n}$ !n $(\mathrm{n}=66)$ ise "bilmiyorum” yanıtını verdikleri belirlenmiştir.

\begin{tabular}{|l|c|c|}
\hline \multicolumn{3}{|l|}{$\begin{array}{l}\text { Tablo 7. Öğrencilerin Hepatit A aşısı ve Hepatit B aşısı olma } \\
\text { durumları hakkındaki bilgi düzeylerinin oranı }\end{array}$} \\
\hline Hepatit A aşısı var mı? & Frekans (N) & Yüzde (\%) \\
\hline Evet & 62 & 32.3 \\
\hline Hayır & 85 & 44.30 \\
\hline Bilmiyorum & 45 & 23.40 \\
\hline Toplam & 192 & 100.0 \\
\hline Hepatit B aşısı var mı? & Frekans (N) & Yüzde (\%) \\
\hline Evet & 76 & 39.60 \\
\hline Hayır & 70 & 36.50 \\
\hline Bilmiyorum & 46 & 24.00 \\
\hline Toplam & 192 & 100.00 \\
\hline
\end{tabular}

Öğrencilerin "kan yolu ile bulaşan hastalıklar açısından risk altında olup olmadıklarına" ilişkin soruya verdikleri yanıtları incelendiğinde \%2.60'ının ( $\mathrm{n}=5)$ "evet", \%97.40’ının ( $\mathrm{n}=187)$ ise" hayır" yanıtını verdikleri görülmektedir.

Öğrencilerin, "hangi hastalıklara karşı aşı uygulandığına" dair bilgilerini saptayan soruya verdikleri yantt incelendiğinde \%44.80'inin ( $\mathrm{n}=86)$ doğru yanıt olan (Hepatit $\mathrm{A}$, Hepatit B, Tetanoz, Grip) yanıtını verdikleri belirlenmiştir. Diğerlerinin yanıtlarında Hepatit C, AIDS (Acquired Immune Deficiency Syndrome), Kırım Kongo Kanamalı Ateş hastalıklarını içeren şıklar mevcuttu. \%10.40’1 (n=20) sadece grip aşısı seçeneğini işaretlemişti.

Öğrencilerin “akciğer tüberkülozunun bulaşma şekli" ile ilgili soruya verdikleri yanıtlar incelendiğinde \%81.30'unun $(\mathrm{n}=156)$ "solunum yolu ile bulaşır" yanıtını verdikleri saptandi (Tablo 8).

Öğrencilerin (verem aşısı her zaman veremden korur mu?) sorusuna verdikleri yanıtlar incelendiğinde $\% 27.60$ ’nın 
$(\mathrm{n}=53)$ “evet”, \%72.40'ının $(\mathrm{n}=139)$ ise "hayır" yanıtını verdikleri belirlenmiştir.

\begin{tabular}{|c|c|c|}
\hline \multicolumn{3}{|c|}{$\begin{array}{l}\text { Tablo 8. Öğrencilerin “akciğer tüberkülozu nasıl bulaşır?” } \\
\text { sorusuna verdikleri yanıtların oranı ve lise türleri değişkenine } \\
\text { göre yanıt oranları }\end{array}$} \\
\hline Akciğer Tüberkülozu nasıl bulaşır? & Frekans $(\mathrm{N})$ & Yüzde (\%) \\
\hline Solunum yolu & 156 & 81.30 \\
\hline Kan yoluyla & 21 & 10.90 \\
\hline Bilmiyorum & 15 & 7.80 \\
\hline Toplam & 192 & 100.00 \\
\hline $\begin{array}{l}\text { Akciğer Tüberkülozu nasıl bulaşır? } \\
\text { (Doğru yanıt verenler) }\end{array}$ & Grup n - \% & $\mathbf{p}$ \\
\hline $\begin{array}{l}\text { Eğitim durumu (Sağllk Meslek } \\
\text { Lisesi/ Diğer Liseler) }\end{array}$ & $\begin{array}{c}51 / 105- \\
(92.70 / 76.60)\end{array}$ & $\mathrm{p}=.002$ \\
\hline
\end{tabular}

Öğrencilere, "bulaşıcı hastalığı olan bir hasta ile temasta yapılması gereken kişisel koruyucu önlemler” sorulduğunda (Eldiven, Maske, Önlük, El yıkama, El dezenfektanı) yanıtıyla \%53.10 $(n=102)$ oranında doğru yanıt verdikleri belirlenmiştir.

Hepatit A aşısı olduklarını ifade eden öğrencilerin cinsiyet, anne eğitim durumu, baba eğitim durumu ve lise türleri değişkenine göre yanıtları Ki-kare testi ile analiz edildiğinde anlamlı farklılık meydana gelmediği ( $\mathrm{p}>.194$; $\mathrm{p}>0,5)$ görülmektedir.

Hepatit B aşısı olduklarını ifade eden öğrencilerin cinsiyet, anne eğitim durumu, baba eğitim durumu ve lise türleri değişkenine göre yanıtları Ki-kare testi ile analiz edildiğinde sadece cinsiyet değişkenine göre anlamlı farklılık meydana geldiği (erkek/kadın oranı 29/47 (\%33.70/\%44.30) ( $\mathrm{p}=.000 ; \mathrm{p} \leq .0 .05)$, buna karşılık anne eğitim durumu, baba eğitim durumu ve eğitim türü değişkenlerine göre anlamlı farklılık meydana gelmediği ( $p>.258 ; \mathrm{p}>0.5)$ görülmektedir.

"Hangi hastalıklara karşı aşı geliştirilmiştir?" sorusuna doğru yanıt veren öğrenciler okudukları programlar açısından incelendiğinde ilk ve acil yardım, odyometri ve tıbbi laboratuvar teknikleri bölümlerindeki öğrencilerin doğru yanıt yüzdelerinin daha yüksek olduğu görülmektedir. “Tüberküloz hastalığı nasıl bulaşır?” sorusuna doğru yanıt veren öğrencilerin, lise türleri ve okudukları program değişkenine göre yanıtları Ki-kare testi ile analiz edildiğinde anlamlı farklılık meydana geldiği $(\mathrm{p}=.002 ; \mathrm{p} \leq 0.05)$ görülmektedir. Yanıtlar incelendiğinde sağlık meslek lisesi öğrencilerinin doğru yanıt verme oranlarının daha yüksek olduğu görülmektedir (Tablo 8).

"Bulaşıcı hastalığı olan hastaya yaklaşırken hangi kişisel koruyucu önlemleri almak gerekir ?"sorusuna doğru yanıt veren öğrencilerin, lise türleri ve okudukları program değişkenine göre yanıtları arasında istatistiksel olarak anlamlı farklılık meydana geldiği $(\mathrm{p}=.000 ; \mathrm{p} \leq 0.05)$ görülmektedir. Yanıtlar incelendiğinde sağlık meslek lisesi öğrencilerinin doğru yanıt verme oranlarının daha yüksek olduğu belirlenmiştir (Tablo 9).

\begin{tabular}{|c|c|c|}
\hline \multicolumn{3}{|c|}{$\begin{array}{l}\text { Tablo 9. Öğrencilerin “Bulaşıcı hastalığı olan hastaya yaklaşırken hangi } \\
\text { önlemleri almak gerekir? ” sorusuna, lise değişkeni ve okudukları pro- } \\
\text { gram değişkenine göre yanıt oranları }\end{array}$} \\
\hline $\begin{array}{l}\text { Bulaşıcı hastalığı olan hastaya } \\
\text { yaklaşırken hangi önlemleri almak } \\
\text { gerekir? (Doğru yanıt verenler) }\end{array}$ & Grup n - \% & p \\
\hline $\begin{array}{l}\text { Eğitim durumu (Sağlık Meslek Lisesi/ } \\
\text { Diğer Liseler) }\end{array}$ & $\begin{array}{c}31 / 71- \\
(56.40 / 51.80)\end{array}$ & $\mathrm{p}=0.000$ \\
\hline $\begin{array}{l}\text { Okuduğu program (Tıbbi } \\
\text { görüntüleme/Tibbi Dokümantasyon/ } \\
\text { İlk ve Acil Yardım/Fizyoterapi/ Ağız } \\
\text { ve Diş Sağlığı/Çocuk Gelişimi/Ody- } \\
\text { ometri/ Tıbbi Laboratuvar Teknikleri) }\end{array}$ & $\begin{array}{c}11 / 8 / 15 / 32 / 14 / 2 / 2 / 18 \\
-(45.80 / 47.10 / 62.0 / \\
71.10 / 56 / 18.20 / \\
50 / 42.90)\end{array}$ & $\mathrm{p}=0.00$ \\
\hline
\end{tabular}

\section{Tartışma}

Sağlık işkolunda çalışanların karşılaştıkları önemli risklerden biri de enfeksiyon hastalıklarıdır. Tüm sağlık kuruluşlarında, özellikle hastanelerde, çalışma ortamının çalışanlar ve hastalar açısından sağlıklı ve güvenli olması, meslek hastalıkları ve toplum sağlığı açısından büyük önem taşımaktadır. Genel olarak, mesleki maruziyete bağlı enfeksiyon hastalıklarının en sık hemşirelerde görüldüğü, daha sonra sırasıyla hekim ve laboratuvar çalışanlarında görüldüğü bildirilmektedir., ${ }^{5,6}$ Günümüzde de enfeksiyon hastalıklarının, sağlık çalışanları arasında en sık mesleki ölüm nedeni olduğu bildirilmiştir. 
$\mathrm{Bu}$ hastalıklardaki enfeksiyon etkenleri, bakteri, virüs, mantar veya parazit olabilir. Enfeksiyon hastalıkları, sağlık çalışanlarına, hastalardaki etkenlerin solunum yolu, kan veya temas yoluyla bulaşması sonucu oluşmaktadır., ${ }^{7,8}$ Sağlık çalışanlarında görülen, mesleki biyolojik etkenler sonucu oluşan hastalıklar, AIDS, kızamık, kızamıkçık, kabakulak, suçiçeği, meningokoksik menenjit, gastrointestinal sistem enfeksiyonu, lejyoner hastalığı, difteri, boğmaca, sarıhumma, Hepatit B, tüberküloz ve herpes enfeksiyonu (uçuk) olarak bildirilmiştir. ${ }^{9}$

Erişkinlerde ciddi ve ölümcül tablolarla seyredebilen kızamık, kızamıkçık, kabakulak ve suçiçeği gibi, birçok aşıyla önlenebilir hastalık etkeninin, sağlık personeline bulaşarak, hastanelerde önemli salgınlara neden olduğu gösterilmiştir. ${ }^{10,11}$

Meslek yüksekokulunda 1. sınıfa devam eden öğrencilerin bulaşıcı hastalıklar ve aşılar konusundaki bilgi düzeylerini ölçmeyi amaçladığımız çalışmamızda, daha önce bulaşıc1 hastalık geçirip geçirmedikleriyle ilgili sorulan soruda öğrencilerin \%13'ünün (evet), \%21.40’ının (hayır) yanıtı verdikleri ve \%65.60’ının ise (bilmiyorum) yanıtını verdikleri görülmektedir. Öğrencilerin daha önce hangi hastalıkları geçirdikleri sorgulandığında \%19'unun kızamık, \%35.40’ının suçiçeği, \%6.30'unun kızamıkçık hastalıklarını geçirdiklerini ifade ettikleri belirlenmiştir. Buna karşılık öğrencilerin \%27.60’ının ise hangi hastalıkları geçirdiğini bilmedikleri saptanmıştır.

Şengöz ve arkadaşları tarafından 384 sağlık personelinde yapılan bir çalışmada, daha önceden kızamık geçirme sorusuna (bilmiyorum) yanıtı \%25, kızamıkçık geçirme sorusuna (bilmiyorum) yanıtı \%46.10, kabakulak geçirme sorusunda (bilmiyorum) yanıtı \%22.70, suçiçeği geçirme sorusunda (bilmiyorum) yanıtı ise \%22.70 olarak bildirilmiştir. $^{11}$

Koruk ve arkadaşları tarafından, bir üniversite eğitim araştırma hastanesinde çalışanlara yapılan çalışmada, çalışanların kızamık, kızamıkçık, suçiçeği geçirme durumları sorgulandığında, kızamık geçirme durumunu bilmeyenler \%39.50, kızamıkçı geçirme durumunu bilmeyenler \%51.30, kabakulak geçirme durumunu bilmeyenler \%30.90, suçiçeği geçirme durumun bilmeyenler ise \%37.20 olarak bildirilmiştir. ${ }^{12}$

Bizim çalışmamız, bu konuda eğitim almamış öğrencilere yapılan bir çalışmadır ve sağlık alanında çalışanlarda yapılan araştırmalardakine benzer ${ }^{11,12}$ sonuçlar belirlenmiştir.

Sağlık Bakanlığı Türkiye Halk Sağlığı Kurumu tarafından, sağlık çalışanlarına uygulanması gereken aşı ve şemaları yönetmeliğinde, sağlık konusunda eğitim gören öğrencilerin eğitimleri döneminde, sağlık kuruluşlarında staj ve sağlık hizmetinde bulundukları için, çalışan sağlık personelinde olduğu gibi bulaşıcı hastalıklar için artmış karşılaşma riski taşıdıkları belirtilmiştir. ${ }^{13}$

Bu nedenle, mesleki riski azaltmaya yönelik olarak tetanoz, difteri, kızamık, kızamıkçık kabakulak, mevsimsel influenza, Hepatit A, Hepatit B, suçiçeği ve özel durumlarda meningokok aşılarını yaptırmaları gerekliliği de belirtilmiştir. ${ }^{13}$ Ayrıca, 2017 yılında yapılan sağlık çalışanlarının sağlığı kongresinde yine aynı yönetmelik doğrultusunda sağlık çalışanlarına yapılması gereken aşılar bildirilmiştir. ${ }^{14}$ Karacaer ve ark. tarafından yapılan bir çalışmanın sonuçlarına göre, sağlık alanında çalışan personelin \%66,70’i hayatının bir döneminde kızamık, kızamıkçık, kabakulak aşısı olduğunu bildirmiştir. Fakat bu üç hastalık için serolojik olarak antikor pozitifliği saptanan personel oranı ise \%5,50 olarak bulunmuştur. Böylece aşılanma bilgisinin doğruluk oranının yetersiz olduğu belirlenmiştir. ${ }^{15}$

Çalık ve arkadaşlarının 84 tıp fakültesi öğrencisinde yaptıkları bir çalışmada ise suçiçeği geçirip geçirmediği ve aşısı olup olmadığını bilmeyen öğrenci oranı (\%42.80), aynı şekilde kızamık için (\%75) kızamıkçık için (\%84.50), kabakulak için (\%70.30) olarak bildirilmiştir. ${ }^{16}$ 
Cılız ve arkadaşlarının 309 sağlık çalışanında yaptıkları bir çalışmada, çalışanların çocukluk dönemi aşılarına ait bilgi durumları incelendiğinde, çocukluk döneminde yapılan aşılardan en çok tetanozu (\%71.50) hatırladıkları, daha sonra sırasıyla kızamık (\%48.50) ve difteri (\%48.20) aşılarını hatırladıkları belirlenmiştir. ${ }^{17}$

Çalışmamızda, öğrencilerin hatırladıkları aşıları sorgulandığında sadece tetanoz aşısı olduğunu bildirme oranı \%19.80, kızamık aşısı olduğunu bildirme oranı \%10.40, hangi hastalıklara karşı aşısı olduğunu bilmediğini ifade eden öğrenci oranı ise \%50 olarak belirlenmiştir.

Yapılan çalışmaların çoğunda araştırma grubu, sağlık işkolunda çalışanlar veya tıp fakültesinde okuyan öğrencilerdir, bu konuda bizim öğrenci grubumuzdan daha bilinçli, farkındalık düzeyleri yüksek ve eğitimli olmaları gerekmektedir, fakat bu çalışmalarda da bilgi ve farkındalık düzeyleri yeterli bulunmamış, hastalık geçirme ve aşılanma öyküsü ile seroprevalans çalışması yapıldığında aşılanma öyküsünün yetersiz olduğu saptanmıştır. ${ }^{12,15,17}$ Bizim çalışmamızda da literatürdeki çalışmalar ${ }^{12,15,16}$ gibi çalışmaya katılan grubun, geçirdikleri hastalıklar ile ilgili bilgilerinin ve yapılan aşılar hakkındaki bilgi düzeylerinin eksik olduğu belirlenmiştir.

Bu konuda, henüz meslek yaşamına başlamadan, hatta staj öncesi dönemde, öğrencilerin sorgulanması ve gerekirse seroprevalans çalışması yapılıp aşılanmalarının gerekli olduğu düşünülmüştür.

Dünya Sağlık Örgütü’nün (DSÖ) tahminlerine göre, sağlık işkolunda çalışanların mesleki temas riski; Hepatit B ve Hepatit C için \%40 oranında bildirilmiş ve HIV/AIDS için bu oranın \%2.50 olduğu belirtilmiştir. Mesleki temasın \%90’ı gelişmekte olan ülkelerde ortaya çıkmaktadır. Sağlık işkolunda görev yapanlarda, Hepatit B enfeksiyon sıklığının diğer meslek gruplarına göre en az 3-6 kat fazla olduğu bildirilmiştir. ${ }^{18}$
Dünya Sağlık Örgütü tarafından Hepatit B hastalığının endemik olduğu, ülkemiz gibi bölgelerde çalışan sağlık personelinde, hastanede çalışılan her yıl başına Hepatit B virüs enfeksiyon riski \% 0.6-1.4 olarak saptanmıştır. Hepatit C seroprevalansının ise dünyada $\% 0,5-2$, ülkemizde ise sağlı personelinde yaklaşık \%1,6, kan donörlerinde \%0,3-0,5 olduğu bildirilmektedir.

Amerika Birleşik Devletleri'nde de sağlık emekçilerinin mesleki bulaşıcı hastalıklara bağlı mortalitesi milyonda 17-57 olarak hesaplanmıştır.9,18,19

Hastalık Kontrol ve Önleme Merkezi (CDC) verilerine göre sağlık çalışanlarında iğne ucu ve perkütan yaralanma sayısı her yıl artmakta, hastane çalışanlarında yılda 385 bin enjektör yaralanması ve günde ortalama 1000 kesici-delici alet yaralanması olduğu bildirilmektedir. Yine kesici-delici alet yaralanmalarının \%60’1 rapor edilmemektedir., ${ }^{9,20}$

Bu konu hakkında farkındalık ve bilgi düzeylerini belirlemeyi amaçladığımız çalışmamızda öğrencilerin hepatit A aşıları olup olmadıkları ile ilgili soruya verdikleri yanitlar incelendiğinde \%32.30'unun (evet), \%44.30 unun (hayır), \%23.40’nın ise (bilmiyorum) yanıtını verdikleri görülmektedir. Çalışmamızda öğrencilerin Hepatit B aşıları olup olmadıkları ile ilgili soruya verdikleri yanıtlar incelendiğinde \%39.60'ının (evet), \%36.50'sinin (hayır), \%24'ünün ise (bilmiyorum) yanıtını verdikleri görülmektedir. Öğrencilerin kan yolu ile bulaşan hastalıklar açısından risk altında olup olmadıklarına ilişkin yanıtları incelendiğinde \%2.60'ının (evet), \%97.40'ünün ise (hayır) yanıtını verdikleri saptanmıştır.

Gülerman ve ark. tarafından 219 tıp fakültesi öğrencisinde yapılan bir çalışmada öğrencilerin Hepatit B hakkındaki bilgileri, aşı durumları, preklinik ve klinik öğrencilerinde sorgulanmıştır. Klinik dönemdeki öğrencilerin bilgi düzeylerinin ve aşılanma oranlarının, preklinik düzeyindeki öğrencilerden daha fazla olduğu belirlenmiștir. ${ }^{21}$ 
Uzun ve ark. tarafından, bir tıp fakültesinde aktif çalışan 222 araştırma görevlisinin Hepatit B ile ilgili durumlarını, bilgi ve davranışlarını değerlendirmek amacıyla yapılan bir çalışmada, Hepatit B aşılanma oranı \%68.40 olarak belirlenmiştir. Çalışmada araştırma görevlilerinin Hepatit B’ye karşı aşı olma ve kendilerinin bağışık durumlarını öğrenme konusunda gerekli duyarlılığı göstermedikleri gözlendiği bildirilmiştir. ${ }^{22}$ Yapılan birçok çalışmada, sağlık çalışanlarının ve sağlık programında eğitim gören öğrencilerin, hepatit hastalığı konusunda farkındalık ve bilgilerinin az olduğu, aşılanma konusunda da oranların istenen

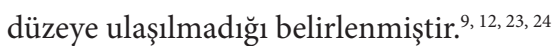

Göktalay ve ark. tarafından, tıp fakültesi, sağlık yüksekokulu ve sağlık hizmetleri meslek yüksekokulu 1. sınıfına devam eden 392 öğrencide, Hepatit B'den korunma ve hastalığın bulaşma yolları ile ilgili yapılan bir çalışmada, öğrencilerin Hepatit B konusundaki bilgilerinin yeterli düzeyde olmadığ 1 görülmüştür. Tıp fakültesi öğrencilerinin diğer fakülte ve yüksekokul öğrencilerinden daha fazla oranda doğru yanıt ortalamasına sahip oldukları saptanmiştır. ${ }^{25}$

Çalışmamızda da literatürle uyumlu olarak ${ }^{9,23,24,25,26}$ benzer sonuçlar bulunmuştur. Özellikle kan yolu ile geçen hastalıklar konusunda kendini risk altında görmeyenlerin oranı çalışma grubumuzda çok yüksektir. Öğrencilerin 1. Sınıfta olması ve bu konuda yeterli bilgilerinin ve eğitimlerinin olmaması bu durumu açıklayabilir.

Tüberkülozla ilgili olarak, gelişmiş ülkelerde yapılan çalışmalarda, sadece mesleki maruziyete atfedilen risk \%3 iken, sağlık çalışanlarında \%5 olarak gösterilmiştir. Ülkemizde yapılan çalışmalarda tüberküloz insidansının sağlık çalışanlarında 2 ile 5 kat daha fazla olduğu gösterilmiştir. ${ }^{9}$

Ülkemizde sağlık çalışanlarında, tüberkülozun topluma göre daha fazla görüldüğü değişik çalışmalarda gösterilmiştir. ${ }^{27}$ Hastanelerde basil ile en fazla karşılaşan çal1şanların, hemşireler ve hizmetli personel olduğu belir- lenmiştir. ${ }^{27}$ Sağlık çalışanlarında, Türkiye rakamına göre, toplumun 10 katı daha fazla tüberküloz görülmektedir. ${ }^{28}$

Tüberkülozda BCG (Bacille Calmette-Guerin) aşısı, kanla ve lenfatik sistemle tüberküloz basilinin yayılmasını engellemektedir. Böylece hayatı tehdit eden milyer, menenjit tüberküloz gibi durumların ortaya çıkışını azaltmaktadır. ${ }^{27}$ Kohort çalışmasının değerlendirildiği bir meta analizde BCG’nin akciğer tüberkülozundan koruyuculuğu bir çalışmada \%44-99 arasında bulunmuş, bir çalışmada ise koruyucu olmadığg belirtilmiştir. ${ }^{29}$

Demir ve ark. tarafından, tüberküloz hakkında bilgi düzeyi konusunda 293 tıp fakültesi öğrencisinde yapılan bir çalışmada, öğrencilerin çoğunun $(\% 62,80)$ tüberkülozun damlacık yoluyla bulaştığını, \%85'inin en sık akciğerde hastalığa yol açtığını bildiği belirtilmiştir, ayrıca tüberkülozla ilgili eğitim almış öğrencilerin almayanlara göre, hastalığın nasıl bulaştığı, risk faktörleri, semptomları, tanıs1nın nasıl konulduğu ve tedavisi ile ilgili konularda anlamlı olarak daha fazla bilgiye sahip oldukları belirtilmiştir. ${ }^{30}$ Aynı çalışmada 42 öğrencinin $(\% 14,30)$ tüberkülozla ilgili hiçbir fikri olmadığı ve bütün katılımcıların \%84,60’ının, BCG aşısının tüberkülozu önlediğini düşündükleri saptanmıştır. ${ }^{30}$

Göğüs hastalıkları hastanesinde çalışan hemşirelerde yapılan bir çalışmada ise (\%98.10) oranında tüberkülozun solunum yoluyla bulaştığı şeklinde yanıt verilmiştir. Tüberküloz kliniğinde çalışanlar, diğer birimlerde çalışanlara göre daha bilgili bulunmuştur. ${ }^{31}$

Çalışmamızda, yine en önemli enfeksiyon hastalıklarından biri olan tüberküloz hastalığının bulaşma şekli ile ilgili olarak öğrencilerin verdikleri yanıtlar incelendiğinde \%81.30’u solunum yolu, \%10.90’ı kan yoluyla bulaştığını ifade etmekte iken, \%7.80'i ise bulaşma yolunu bilmediklerini belirtmişlerdir. Öğrencilerin (verem aşısı her zaman veremden korur mu?) sorusuna verdikleri yantlar incelendiğinde \%27.60’ının (evet), \%72.40’ının ise (hayır) ya- 
nıtını verdikleri görülmektedir.

(Tüberküloz hastalığı nasıl bulaşır?) sorusuna doğru yanıt veren öğrencilerin lise türleri ve okudukları program değişkenine göre, yanıtlarında anlamlı farklılık meydana geldiği $(\mathrm{p} \leq 0.05)$ görülmektedir. Yanıtlar incelendiğinde, sağlık meslek lisesi öğrencilerinin doğru yanıt verme oranlarının daha yüksek olduğu saptanmıştır. Çalışmamızda tüberküloz konusunda bilgi düzeyinin yetersiz olmadığı, eğitim alan öğrencilerin daha doğru yanıtlar verdikleri ve literatürdekine benzer ${ }^{30,31}$ sonuçlara ulaşıldığg görülmüştür. Ülkemizde ilk olarak 1947 yılında gerçekleştirilen tüberküloz eğitimi ve propaganda haftasında; radyo konuşmaları, film gösterileri ile halkı bilgilendirme çalışmaları, halkevlerinin çalışmaları ve BCG aşısının kullanımının yaygınlaştırılması çalışmaları yapılmıştır. $\mathrm{Bu}$ etkinlikler okullarda, toplum içinde, iletişim araçları da kullanılarak hala devam etmektedir. ${ }^{32}$ Tüberküloz konusunun, diğer hastalıklara göre toplumsal eğitiminin daha fazla yapılmasının da alınan sonuçlarda etkili olduğu düşünülmüştür.

Çalışmamızda, öğrencilere bulaşıcı hastalığı olan bir hasta ile temasta yapılması gereken kişisel koruyucu önlemler ile ilgili soru sorulduğunda (Eldiven, Maske, Önlük, El yıkama, El dezenfektanı) yanıtıyla \%53.10 oranında doğru yanıt verildiği belirlenmiştir.

"Bulaşıcı hastalığı olan hasta ile temasta, hangi önlemleri almak gerekir?” sorusuna doğru yanıt veren öğrencilerin lise türleri ve okudukları program değişkenine göre yanıtlarda anlamlı farklılık meydana geldiği $(\mathrm{p} \leq 0.05)$ görülmektedir. Yanıtlar incelendiğinde sağlık meslek lisesi öğrencilerinin doğru yanıt verme oranlarının daha yüksek olduğu görülmektedir.

Literatürde incelenen çalışmaların çoğunda, kişisel koruyucu ekipman kullanım oranının oldukça yüksek olduğu belirlenmiştir ${ }^{33-41}$ Eğitim verilmeden önceki oranların, eğitim verildikten sonraki oranlara göre daha düşük olduğu, klinik deneyimleri olmayan öğrencilerin kişisel koruyucu ekipman kullanım bilgilerinin eksik olduğu belirtilmiş- tir. ${ }^{35-41}$ Çalışmamızda bu konuda saptanan bilgi düzeyinin de orta düzeyde olduğu görülmüştür, eğitimin sonuçları etkilediği belirlenmiştir.

Sonuç olarak, sağlık işkolunda çalışacak öğrencilerin geçirmiş oldukları bulaşıcı hastalıklar, staj öncesi dönemde sorgulanmalı, eksik olan aşıları belirlenmeli ve gerekirse seroprevalans çalışması yapılarak aşılanmaları sağlanmalıdır. Hastalıkların bulaşma yollarının öğretilmesi, alınması gereken tüm koruyucu önlemler konusunda eğitim verilmesi, önemli oranda mesleki enfeksiyon hastalıkları riskini azaltacak, iş verimini etkileyecek ve toplum sağlığ 1 açısından önemli olacaktır. Çalışmamızın kısıtlılığı tek okulda yapılmış olmasıdır, ama kesitsel olduğu halde literatürde de sonuçların benzer olduğu gözlenmiştir. Mesleki enfeksiyon hastalıklarını önlemek için tüm eğitimlerin erken dönemde yapılması ve gereken koruyucu önlemlerin, eğitim dönemi başlarken alınması gerektiği sonucuna varılmıştır.

\section{Çalışmanın kısıtlılı̆̆ı}

Tek bir meslek yüksekokulunda yapılmış olması çalışmanın kısıtlılığ olarak düşünülmüştür. 
Sakarya Tip Dergisi 2020;10(1):1-10

SARAR ve Ark., Meslek Yüksekokulunda Eğitim Gören Öğrencilerin Bulaşııı Enfeksiyonlar Hakkındaki Bilgi ve Farkındalık Düzeyleri

\section{Kaynaklar}

1. Oğan H. Sağlık Çalışanı. Sağlı Çalışanlarının Sağhl̆̆ı Çalışma Grubu, Sağlık Çalıșanları İçin işçi Sağlığı ve Güvenliği. 1. Baskı. Ankara: TTB Yayınları.2014.s:10-14.

2. Meydanlıoğlu A. Sağlık çalışanlarının sağhlğı ve güvenliği. Balıkesir Sağlık Bilimleri Dergisi 2013;2(3),192-199.

3. Beșer A. Sağlık Çalışanlarının Riskleri. Dokuz Eylül Üniversitesi Hemşirelik Yüksekokulu Elektronik Dergisi 2012,5(1),39-44.

4. Sağlık çalı̧̧anları bulaşııı hastalıklar açısından risk altında mıdır? Sağlık Çalışanlarının Meslek Riskleri.1. Baskı. Ankara: TTB Yayınları.2008.s:9-10.

5. Hasde $M$, Oğur R. Occupational infectious diseases among healthcare workers. TAF Prev Med Bull 2011; 10(4): 495-500.

6. Waclawik J, Gasiorowski J, Inglot M, Andrzejak R, Gladysz A. Epidemiology of occupational infectious diseases in health care workers. Med Pr 2003; 54(6): 535-541.

7. Emiroğlu C, Sağllk sektöründe mesleki riskler ve hukuksal düzenlemeler. Türk Tabipler Birliği Mesleki Sağhlk ve Güvenlik Dergisi 2012;43: 16-25.

8. Akarsu H, Güzel M. Biyolojik Tehlike ve Riskler. Sağlik Sektöründe Tehlike ve Riskler. Ankara: ÇASGEM Yayini 2016.s:18-21.

9. Zencir M, Mesleksel bulaşıcı hastalıklar: Sağlık çalışanlarının sağllğı örneği. Türk Tabipleri Birliği Mesleki Sağllk ve Güvenlik Dergisi 2014; 60-9.

10. Botelho-Nevers E, Gautret P, Biellik R, Brouqui P. Nosocomial transmission of measles: an updated review. Vaccine. 2012; 30(27):3996-4001.

11. Şengöz M, Pişkin N, Aydemir H ve ark. Sağlık Personelinde Kızamık, Kızamıkçık, Kabakulak ve Suçiçeği Seroprevalansinın Değerlendirilmesi. Klimik Dergisi 2019; 32(1): 46-51.

12. Koruk İ ve ark, Sağlık Çalışanlarında Mesleki Bulașıcı Hastalıklara Karșı Așılanma. Klimik Dergisi 2014; 27(2): 48-56.

13. Risk Grubu Așılamaları. Să̆lık Bakanlığı, Türkiye Halk Sağlğ̆ı Kurumu 2016. Sayı: 21001706/131.99 Erişim Tarihi: 28.06.2018

14. Aktaş F. Olgularla Eksik Așıll; Nasıl Tamamlayalım? Eksik Aşılı Sağlı Çalışanı. 33. Ankem Kongresi Bildiri Kitabında; 2-6 Mayıs 2018; İstanbul, Türkiye 2018.s.35-36.

15. Karacaer Z, Öztürk İ̈, Çiçek $H$ ve ark. Sağllk çalışanlarının bağışıklanma ile ilgili bilgi düzeyleri, tutum ve davranışları. TAF Prev Med Bull 2015;14:353-363.

16. Çalık Ș, Tosun S, Başoğlu MT, Sayın S. Tip Fakültesi Öğrencilerinde Kızamık Kızamıkçık, Kabakulak ve Suçiçeği Seroprevalansının Araştırılması. Flora 2017;22(2):73-75.

17. Cilız N, Gazi H, Ecemiș T, Șenol Ș, Akçalı S, Kurutepe S. Sağlık çalışanlarında kızamık, kızamıkçık, kabakulak, suçiçeği, difteri, tetanos ve hepatit B seroprevalansı. Klimik Dergi 2013; 26(1): 26-30.

18. Mazıcan N, Türk M. Sağlık Çalışanlarında Biyolojik Risk Etkenleri Kaynakh Meslek Hastalıkları. Sağlık Çalışanlarının Sağlı̆̆ı 6. Ulusal Kongre kitabında; 21 -22 Ekim 2017; İstanbul, Türkiye. Türk Tabipleri Birliği Yayınları.2018.s:227-229.

19. Sepkowitz KA, Eisenberg L. "Occupational deaths among healthcare workers". Emerging Infectious Diseases.2005;11 (7):1003-8.

20. Centers for Disease Control and Prevention. Workbook for designing, implementing, and evaluating a sharps injury prevention program. 2004: 3-13.

21. Gülerman H F, Güven B, Katırcıŏ̆lu M, Akyüz E. Tip Fakültesi Öğrencileri Hepatit B Farkindalı Düzeyleri. K.Ü Tip Fak Derg 2017; 19(2): 66-72.

22. Uzun E, Akçam F, Zengin E, Kişioğlu A, Yaylı G. Süleyman Demirel Üniversitesi Tip Fakültesi Araștırma Görevlilerinin Hepatit B enfeksiyonu ile ilgili durumlarının, bilgi düzeylerinin ve tutumlarının değerlendirilmesi. Süleyman Demirel Üniversitesi Tip Fakültesi Dergisi 2008; 15(1): 22-27.
23. Karataş B, Çelik S, Koç A. Hemșirelik Öğrencilerinin Kesici-Delici Aletlerle Yaralanmaya İlişkin Bilgi Düzeylerini ve Tutumlarının İncelenmesi, Bozok Tip Dergisi 2016;6(4):21-9.

24. Gülaçtı U. Elazı̆̆ Harput Devlet Hastanesi Çalışanlarında Hepatit B ve C Seroprevalansı. Konuralp Tip Dergisi 2013;5(3):5-8,

25. Gökaltay T, Özyurt B. Celal Bayar Üniversitesinde Sağlık Personeli Yetiștiren Fakülte ve Yüksekokul Ögrencilerinde Hepatit B Seroprevalanst ve Hepatit B Bilgi Düzeyleri. Viral Hepatit Dergisi 2010;15(1):13-21.

26. Yıldırım A, Özpulat F. Sağllk Meslek Lisesi Öğrencilerinin Mesleki Riskler Konusunda Bilgi ve Farkindalık Düzeyleri. Sürekli tıp eğitimi dergisi 2015; 24(1):18-25.

27. Tüberküloz tanı ve tedavi rehberi. Kara F,editör.2.Baskı. Ankara:Artı6 Medya Tanıtım Matbaa;2019.s:195-203.

28. Özkara Ș. Sağlık Çalışanlarında Meslek Hastalı̆̆ı Olarak Tüberküloz; Dünya'daki ve Türkiye'deki Durumu. Sağltk Çalıșanlarının Sağhlğ 6 6. Ulusal Kongre kitabında 21-22 Ekim 2017; İstanbul, Türkiye. Türk Tabipleri Birliği Yayinlarl; 2018.s: 31-40.

29. Abubakar I, Pimpin L, Ariti C, et al. Systematic review and metaanalysis of the current evidence on the duration of protection by bacillus Calmette-Guérin vaccination against tuberculosis. Health Technol Assess. 2013;17(37):1-372.

30. Demir M, Aslan E, Taylan M. Tip Fakültesi Ögrrencilerinin Tüberküloz Bilgi Düzeyleri. Dicle Tip Dergisi.2016; 43(2): 265-270.

31. Yllmaz F T, Tuna A G, Çevik Y, Kllıçaslan N. Göğüs Hastalikları Hastanesinde Görev Yapan Hemşirelerin Tüberküloza İlişkin Bilgi Düzeyleri. İ.Ü.F.N. Hem. Derg. 2011;19(1):37-44.

32. İlter H, Kabasakal E, Yildırım A. Mutlu S.M, Baykal F. Türkiye'de Verem Savașı 2017 Raporu. Halk Sağllğı Genel Müdürlüğü Tüberküloz Dairesi Bașkanlı̆̆ı. Ankara, 2017.

33. Kepenek E, Șahin-Eker HB. Bir Devlet Hastanesinde Çalı̧̧anlarda Meydana Gelen Kesici ve Delici Alet Yaralanmalarının Değerlendirilmesi. Klimik Dergisi 2017; 30(2):78-82.

34. Beşer A, Topçu S. Sağlk Alanında Kişisel Koruyucu Ekipman Kullanımı. Dokuz Eylül Üniversitesi Hemşirelik Yüksekokulu Elektronik Dergisi 2013;6(1):241-247. http://www. deuhyoedergi.org

35. Karabiber C, Sarb G, Kerman B, Savaş N. Bir Tip Fakültesi Hastanesi Sağllk Çalışanlarında İs Sağlı̆̆ı-Güvenlĭgi Durumu ve Risk Faktörleri. Sağlık Bilimleri Ve Meslekleri Dergisi 2018;5(3):3.

36. Savcı C, Şerbetçi G, Kıllıç Ü .Sağlık Disiplini Öğrencilerinin İş Sağlı̆̆ı ve Güvenliği Konusunda Eğitim Alma ve İș Kazasına Maruz Kalma Durumu. Sağlik ve Hemșirelik Yönetimi Dergisi 2013;6(1):241-247.

37. Hakyemez H F, Demir B, Özkalp H, Özkalp B. Paramedik Öğrencilerinin Çalışan Güvenliğ Konusundaki Görüşlerinin İncelenmesi. Hastane Öncesi Dergisi 2018;3(2):91-102.

38. Savcı C, Şerbetçi G, Kıllıç Ü. Sağlık Disiplini Öğrencilerinin I̦ș Sağllğı ve Güvenliği Konusunda Eğitim Alma ve İș Kazasına Maruz Kalma Durumu. Sağlk ve Hemşirelik Yönetim Dergisi 2018;1(5):36-47.

39. Çelik Y, Akduman D, Kiran S. Sağlık çalışanları ve öğrencilerin kan ve vücut stvilarıyla bulaşan enfeksiyonlar, enfeksiyon kontrol önlemleri hakkındaki bilgi düzeyleri, temas slklıkları, serolojik durumları ve hepatit B aşılanma durumlarının değerlendirilmesi. Türkiye Klinikleri J Med Sci 2010;30(4):1246-55.

40. Kim KM, Kim MK, Chung YS, Kim NC. Knowledge and performance of the universal precautions by nursing and medical students in Korea. Am J Infect Control 2001;29(5):295- 300.

41. Doğu Ö, Karabay O. Hemşirelik ve Ebelik İntörn Öğrencilerine Enfeksiyon Kontrol Eğitim Programı. Online Türk Sağlık Bilimleri Dergisi 2016;2(1):1-10. 